\title{
Training of Senior Scientific and Pedagogical Staff: Present State and Problems
}

\author{
Yu. N. Berezhnaya ${ }^{1}$, V. A. Gurtov ${ }^{2}$ \\ Petrozavodsk State University \\ Petrozavodsk, Russia \\ 1'yulia@petrsu.ru, ${ }^{2}$ vgurt@psu.karelia.ru
}

\author{
G. I. Dmitriev \\ Saint-Petersburg Electrotechnical University "LETI" \\ St. Petersburg, Russia \\ sznmc@mail.ru
}

\begin{abstract}
Postgraduate training as the third level of higher education is the main institution in the field of preparation of candidates of science, which ensure the reproduction of senior scientific staff. Implementation of measures aimed at optimizing the network of dissertation councils, increased demands to organizations at which are created dissertation councils, as well as to the performance of research activity of dissertation council's members and quality of the presented dissertations. As a result, the number of defenses of dissertations for the degree of candidate of sciences in the period from 2015 to 2018 decreased from 12.5 thousand to 8.7 thousand defenses. At the same time was reduced the enrollment and graduation of graduate students. The paper aims to analyze the dynamics of the training processes and certification of candidates of sciences from the position of providing the economy with senior scientific staff.
\end{abstract}

Key words - senior scientific staff; staff training; postgraduate training; defend of a thesis; dissertation council; admission to graduate school

\section{PostgRAdUATE TRAINING OF SCIENTIFIC AND PEDAGOGICAL PERSONNEL}

The number of graduate students reached a peak of 157 thousand people in 2010, including 108 thousand studying at the expense of the budget funds. At the end of 2017, this indicator decreased to 93 thousand students (a decrease of $41 \%$ ), including 65 thousand trained at the expense of budget funds (a decrease of $40 \%$ ). The maximum number of budget graduate students was observed in 2003 and was equal to 121 thousand students; the decrease of budget graduate students by 2017 was equal to $46 \%$.

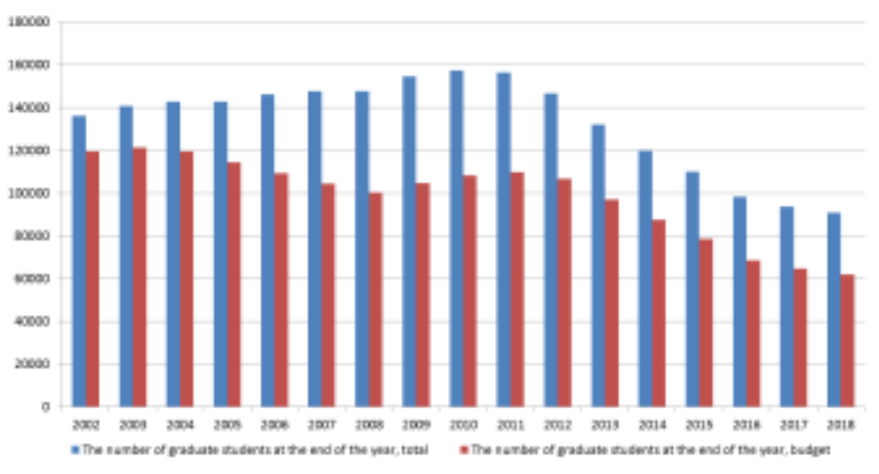

Fig. 1. Dynamics of the graduate students number
The maximum enrollment of graduate students was in 2009 and was equal to 55 thousand students. By 2017, the admission of graduate students fell to 26 thousand people (a decrease of $53 \%$ ). The maximum graduation of students was observed in 2012 (35 thousand students) and it decreased to 18 thousand people by 2017 (a decrease of 49\%). Graduation of budget students in the same years was equal to 25 and 13 thousand students, respectively (a decrease of 45\%).

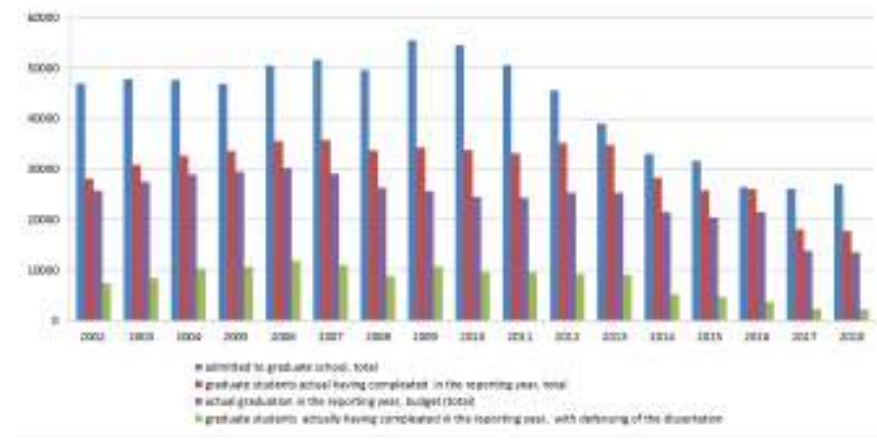

Fig. 2. Dynamics of admission and graduation of students

The analysis of graduate admission quotas proportion for 2014-2016 for educational and scientific organizations in the context of ministries and departments in relation to general graduation admission quotas showed the following. For organizations of the academic sector, the admission quotas have increased from $9 \%$ to $13 \%$; for organizations subordinate to the Government of the Russian Federation, the number also increased from $12 \%$ to $16 \%$. For organizations of the Ministry of Healthcare and the Ministry of Agriculture of the Russian Federation, this indicator has not changed significantly and remained at the level of 6-7\%. For educational organizations of the Russian Ministry of Education and Science, the proportion of admission quotas decreased from $58 \%$ to $52 \%$.

In 2017,83 thousand graduate students, or $89 \%$ of all graduate students, studied at the universities. Budgetary admission (admission quotas) is equal to $60 \%$ of the total admission. Reduction of budgetary admission was in phase with the reduction in total admission.

Since the main reduction in admission quotas has affected educational institutions of the Ministry of Education and Science of the Russian Federation, the distribution of admission quotas in graduate school, taking into account the 
status of educational organizations: federal and national research universities, is as follows. The admission quotas for 10 federal universities and 29 national research universities under the jurisdiction of the Russian Ministry of Education and Science has increased from 5.0 thousand to 5.4 thousand in the same period, which corresponds to an increase in the share from $47 \%$ to $65 \%$.

With such a redistribution of the admission to graduate school, 250 universities - classical, technical, pedagogical, and economic universities - suffered from two or more times less budgetary admission from 5.6 thousand to 2.9 thousand students. At the same time, the admission in universities under the jurisdiction of the Ministry of Healthcare and the Ministry of Agriculture of Russia, in the same period from 2014-2016 did not change.

10 thousand students, or $11 \%$ of all graduate students, studied in the academic sector in 2017. The admission quotas for organizations in the academic sector amounted 2 thousand students and did not change. At the same time, the proportion of admission quotas for organizations in the academic sector increased from $9 \%$ to $13 \%$.

\section{THE DEFENSE OF CANDIDATE DISSERTATIONS}

During the past 10 years, the number of defense of candidate dissertations has reduced monotonously. The maximum number of defenses (23 thousand) was observed in 2011. The number of defenses dropped significantly and in 2018 was equal to 8.7 thousand defenses of candidate dissertations. At the same time, the proportion of people who defended their dissertation after graduate training monotonously increased from $64 \%$ to $78 \%$. The $78 \%$ indicator includes "post-defense" of graduate students within four years after completion of postgraduate studies. Such an increase was observed for all awarded branches of science, with the exception of pharmaceutical and geographical sciences. It is important that in pharmaceutical and geographical sciences, the number of defense of candidate dissertations is only $1.5 \%$ of the total number of defenses of candidate dissertations.

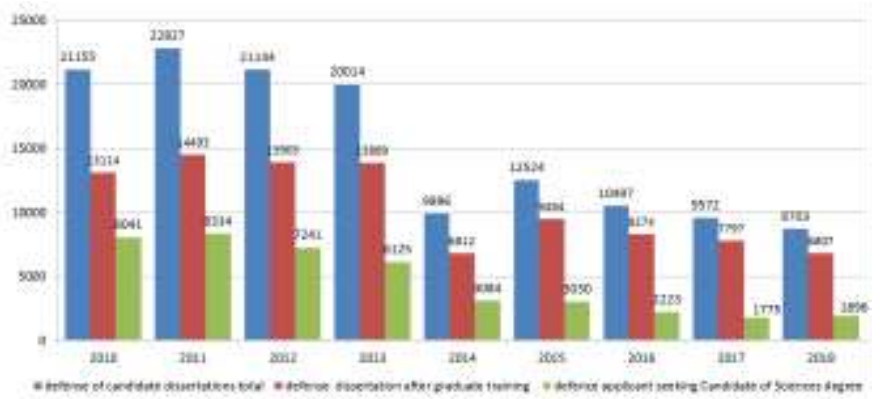

Fig. 3. Number of candidate dissertations defenses

The number of people who defended the dissertation after finishing graduate school reduces annually - from 8.3 thousand people in 2011 to 1.9 thousand people in 2018. The proportion also decreased from $36 \%$ to $22 \%$. Such defenses are not widely spread in natural science, technical, and sociological branches of science, and are widely spread in medical, pedagogical, and legal sciences.

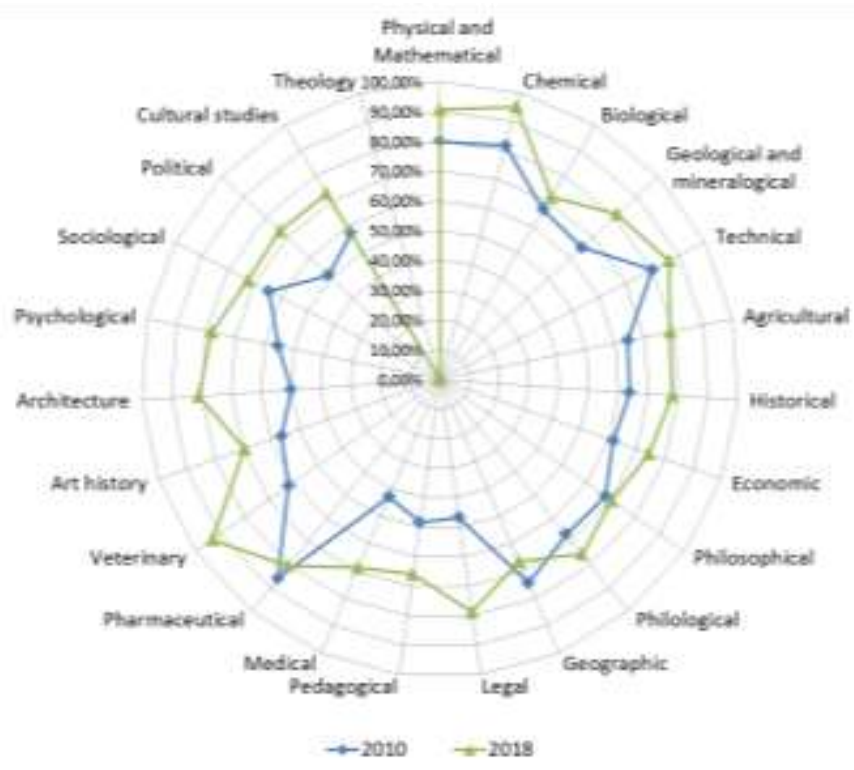

Fig. 4. The proportion of people who defended their dissertation after graduate training

Traditionally, the efficiency of postgraduate training is assessed as the ratio "graduation with the defense of the dissertation to general graduation". In 2018, graduation from graduate school was equal to 17.8 thousand, including 2.2 thousand with the defense of the dissertation, which corresponds to an efficiency of $12.4 \%$. In previous years, this figure was $25-30 \%$, but since 2014 , it began to decline monotonously from $18.4 \%$ to $12.4 \%$.

Traditional efficiency does not take into account the fact that some graduate school graduates defend their dissertations in one year, two or more years after graduate school. Considering "post-defenses", the value of performance indicators of graduate school by the criterion of "the number of defenses after graduate school with accumulation to total graduation" in period from 2000 to 2014 increased from $30 \%$ to $49 \%$. For various scientific specialties, the efficiency of postgraduate studies taking into account "post-defenses" is in the range from $86 \%$ for graduate students in medical specialties, to $30 \%$ in "Earth Sciences" specialties.

Retention of graduate students during their studies is calculated through the indicator "admission of 3 or 4 years ago minus graduation of current year". This indicator is in the range from 35\% to 48\% between 2009 and 2016. In 2018, this indicator was equal to $45 \%$.

In the statistics of the Federal State Statistics Service on work of graduate school there is no data on the number of graduate students by years of study, which makes it impossible to trace the dynamics of retention of graduate students by years of study. Since 2014, admission in the fields of training (the All-Russian classifier of specialties by education) replaced the admission to graduate school for scientific specialties (the AllRussian classifier of specialties of the senior scientific qualification). From 2014 to 2017, the Federal State Statistics Service published the information on the number of graduate 
students by years of study with accumulation in scientific specialties and in areas of training. However, these data do not allow carrying out the analysis of retention by year of study, since they include three and four-year training programs.

TABLE I. THE STRUCTURE OF THE NUMBER OF GRADUATE STUDENTS BY YEARS OF STUDY

\begin{tabular}{|c|c|c|c|c|c|}
\hline The number of graduate students at the end of the year & 2014 & 2015 & 2016 & 2017 & 2018 \\
\hline 1st year students, total in field of training & 32859 & & & & \\
\hline $2 \mathrm{nd}-5^{\text {th }}$ year students, total in scientific specialties & 87009 & & & & \\
\hline $1 \mathrm{t}$ and 2 nd year students, total in field of training & & 60449 & & & \\
\hline 3 rd -5 th year students, total in field of training & & 49487 & & & \\
\hline 1 st -3 rd year students, total in field of training & & & 82750 & & \\
\hline 4 th -5 th year students, total in field of training & & & 15602 & & \\
\hline $1 \mathrm{st}-4$ th year students, total in field of training & & & & 91922 & \\
\hline 5 th year students, total in field of training & & & & 1601 & \\
\hline 1 - 5 года обучения, total in field of training & & & & & 90823 \\
\hline Total & 119868 & 109936 & 98352 & 93523 & 90823 \\
\hline
\end{tabular}

The overall efficiency indicator "graduation with the defense of a dissertation after the completion of the graduate school in 2018 (6.8 thousand people) to admission to graduate school of 4 years ago in 2014 (32.9 thousand people)" amounted to only $21 \%$. This indicator takes into account the retention and defense of dissertations after completing graduate studies for at least 4 years.

\section{THE REQUIRED NUMBER OF SENIOR SCIENTIFIC STAFF}

The following basic principles are used to predict the number and dynamics of senior scientific staff:

1. Ensuring the reproduction of senior scientific staff at the current moment within the framework of the Nomenclature of scientific specialties.

2. Ensuring the reproduction of senior scientific staff in accordance with the standards in the framework of the Nomenclature of scientific specialties.

As the quantitative indicators of forecasting is used the annual additional demand for senior scientific staff, defined as the number of workers with advanced degrees who must additionally enter the economy to ensure the planned volume of production of goods or services.

Calculation of annual additional need is based on the number of students, regulatory requirements for the degree of teaching staff and standard for the number of students to one teaching staff. The minimum required number of teachers with academic degrees, providing training for bachelors, specialists and masters in universities to reimburse the natural-age retirement for the university sector was equal to 4,250 candidates of sciences in 2016. Taking into account that fulltime employees and graduate students of the university sector defended 7368 candidate dissertations, the higher education sector fully satisfies its own need for senior scientific staff.

The annual estimated additional need for senior scientific staff of the state and entrepreneurial sectors of science amounts 2170 candidates of science. According to the reports of the dissertation councils, in 2017, 1,351 full-time employees and graduate students of the state and entrepreneurial sectors of science defended candidate dissertations.

The analysis of the annual additional needs of the scientific sector in senior scientific staff shows that these organizations do not replenish the number of senior scientific staff themselves by defending dissertations by graduate students and employees working in the scientific sector.

\section{PRoblematic ISSUES OF GRADUATE TRAINING}

Among the problematic issues that need to be addressed are the aforementioned reduction in training volumes, which leads to the fact that the academic sector cannot reproduce their own scientific staff. They also include employment in the period after graduate school until the defense of the dissertation. Approximately half of the theses defense by postgraduate students takes place in the period after 1-3 years after graduation. We can increase this indicator (post-defenses) if we ensure temporary (up to three years) employment of these persons in the field of the dissertation at the university or scientific organization where the dissertation is prepared.

The outflow of candidates of sciences from science and education after the defense is problematic.

Based on the analysis of publication activity reflected in the resource eLIBRARY.RU, within five years after the defense of the dissertation in 2010, it turned out that only $10 \%$ of candidates of science have more than five publications, what means, they are really engaged in the development of scientific knowledge. Another $24 \%$ of candidates of science work in fields related to science and education, as they have from one to five publications. They are passive in publication activity, and, consequently, in scientific activity, but still maintain a high level of their qualifications. Thus, only a third of the candidates of science continues to work in the field of science and education. The remaining two-thirds do not publish any materials; therefore, their activities are in the field of management and other sectors of the economy.

One of the reasons for the emergence of problem areas is the low level of funding for graduate training. The basic by 
head budgetary funding in the field of senior staff training for the training programs of scientific and pedagogical staff in graduate school of higher education organizations in 2019 is $102-135$ thousand rubles, depending on the status of the field of training / specialty. These values for a graduate student do not differ from the costs for a bachelor / specialist / master.

The annual cost of graduate student training with full cost recovery at Moscow State University is equal to 420 thousand rubles, and at the Higher School of Economics - 489 thousand rubles, which is close to the real costs of a graduate student training.

\section{CONCLUSION}

The analysis of problematic issues of postgraduate training shows that it is necessary to implement a system of incentives that provide motivation for master graduates and specialists for admission and successful completion of graduate school, ensuring:

- Scholarship not lower than the average salary in the region;

- Employment on the dissertation profile for a period of 1 to 3 years between graduation from the graduate school and the defense of the dissertation;

- Guaranteed employment after defending a thesis with a salary of at least twice the average in the region.

Basic by head budgetary funding in the field of senior scientific staff training for training programs of scientific and pedagogical staff in graduate school for higher education organizations needs to be increased at least twice.

For universities under the jurisdiction of the Ministry of Science and Higher Education of the Russian Federation, it is necessary to increase the admission quotas for graduate school.

For the scientific justification of volumes and fields of postgraduate training, it is necessary to formulate a forecast for senior scientific staff in high-tech sectors of the economy: healthcare, nuclear industry, shipbuilding, aerospace industry, and state and municipal government.

\section{REFERENCES}

[1] Senashenko V.S. Problems of improving Russian graduate school. $V$ sbornike: Vysshaya shkola: opyt, problemy, perspektivy materialy XII Mezhdunarodnoj nauchno-prakticheskoj konferencii: v 2 chastyah. [In the collection: Higher school: experience, problems, prospects materials of the XII International scientific and practical conference: in 2 parts]. RUDN University Publ., 2019. Pp. 31-35. (In Russian)
[2] Karavaeva E.V., Malandin V.V., Mosicheva I.A., Teleshova I.G. Postgraduate study as a level of higher education: state, problems, possible solutions. Vysshee obrazovanie v Rossii [Higher education in Russia]. 2018. V. 27. No. 11. Pp. 22-34. (In Russian)

[3] Rodachin V.M. The modern mission of graduate school as a third level of higher education. Obrazovanie i nauka v Rossii $i$ za rubezhom. [Education and science in Russia and abroad]. 2018. No 12 (47). Pp. 224-234. (In Russian)

[4] Berezhnaya Yu.N., Gurtov V.A. Graduate School in the New Realities. Universitetskoe upravlenie: praktika i analiz. [University Management: Practice and Analysis]. 2017. V. 21. No. 3. P. 57-65. (In Russian)

[5] Bednyj B.I., Chuprunov E.V. Modern Russian postgraduate study: current trends of development. Vysshee obrazovanie v Rossii [Higher education in Russia]. 2019.Vol. 28. No. 3. Pp. 9-20. (In Russian)

[6] Бодров А.В. Диплом об окончании аспирантуры est диссертация? // Высшее образование в России. 2018. Том 27. № 7. С. 79-85.

[7] Bodrov A.V. Postgraduate diploma est dissertation? Vysshee obrazovanie v Rossii [Higher education in Russia]. 2018. Vol. 27. No. 7. Pp. 79-85. (In Russian)

[8] Plan meropriyatij (dorozhnaya karta) po optimizacii seti sovetov po zashchite dissertacij na soiskanie uchenoj stepeni kandidata nauk, na soiskanie uchenoj stepeni doktora nauk», utverzhden Minobrnauki Rossii 23.08.2016 g. s izmeneniyami, vnesennymi 25.06.2018. [The action plan (roadmap) for optimizing the network of councils for the defense of dissertations for the degree of candidate of sciences, for the degree of doctor of sciences, "approved by the Ministry of Education and Science of Russia on 08.23.2016 as amended on 06.25.2018] [Electronic resource] - Website of the Higher Attestation Commission at the Ministry of Science and Higher Education of the Russian Federation. URL: http://arhvak.minobrnauki.gov.ru/documents, free. (Date accessed: 10.10.2019). (In Russian)

[9] Rabota aspirantury i doktorantury po Rossii, federal'nym okrugam, sub"ektam RF, ekonomicheskim rajonam, otraslyam nauki $i$ special'nostyam, tipam organizacij, akademiyam nauk za 2002-2018 gody. Tablicy po forme otchetnosti 1-NK. [Postgraduate and doctoral studies in Russia, federal districts, constituent entities of the Russian Federation, economic regions, branches of science and specialties, types of organizations, academies of sciences for 2002-2018. Tables on the reporting form 1-NK]. M.: GMC Goskomstat of Russia Publ. 2019. (In Russian)

[10] Obshcherossijskij klassifikator special'nostej vysshej nauchnoj kvalifikacii (OKSVNK) OK 017-2013: prikaz Federal'nogo agentstva po tekhnicheskomu regulirovaniyu i metrologii ot 17.12.2013 g. № 2255-st. [The All-Russian Classifier of Specialties of Higher Scientific Qualification (OKSVNK) OK 017-2013: Order of the Federal Agency for Technical Regulation and Metrology of December 17, 2013 No. 2255-st]. Moscow: Standartinform Publ, 2014.28 p. (In Russian)

[11] "OK 009-2016. The All-Russian Classifier of Specialties by Education "(adopted and enforced by the Order of Rosstandart dated 08.12.2016 N 2007-ст) (OKCO). Konsul'tatPlyus. [ConsultationPlus]. URL: http://www.consultant.ru/document/cons_doc_LAW_212200/, The title from the screen. Russian language (Date of treatment: 11.10.2019) (In Russian)

[12] Scientific Electronic Library eLIBRARY.RU [Electronic resource]. URL: https://elibrary.ru/, free. The title from the screen. Russian language (Date accessed: 11.10.2019) (In Russian) 